\title{
Bortezomib in the rapid reduction of high sustained antibody titers in disorders treated with therapeutic protein: lessons learned from Pompe disease
}

\author{
Suhrad G. Banugaria, MBBS ${ }^{1}$, Sean N. Prater, MD, MRes ${ }^{1}$, Judeth K. McGann, MD², \\ Jonathan D. Feldman, MD², Jesse A. Tannenbaum, MD², Carrie Bailey, BS, CCRC ${ }^{3}$, Renuka Gera, MD, \\ Robert L. Conway, MD, David Viskochil, MD, PhD³, Joyce A. Kobori, MD ${ }^{5}$, Amy S. Rosenberg, MD ${ }^{6}$ \\ and Priya S. Kishnani, MD ${ }^{1}$
}

Purpose: High sustained antibody titers complicate many disorders treated with a therapeutic protein, including those treated with enzyme replacement therapy, such as Pompe disease. Although enzyme replacement therapy with alglucosidase alfa (Myozyme) in Pompe disease has improved the prognosis of this otherwise lethal disorder, patients who develop high sustained antibody titers to alglucosidase alfa enter a prolonged phase of clinical decline resulting in death despite continued enzyme replacement therapy. Clinically effective immune-tolerance induction strategies have yet to be described in the setting of an entrenched immune response characterized by high sustained antibody titers, wherein antibody-producing plasma cells play an especially prominent role.

Methods: We treated three patients with infantile Pompe disease experiencing marked clinical decline due to high sustained antibody titers. To target the plasma cell source of high sustained antibody titers, a regimen based on bortezomib (Velcade) was used in combination with rituximab, methotrexate, and intravenous immunoglobulin.

Results: The treatment regimen was well tolerated, with no obvious side effects. Patient 1 had a 2,048-fold, and patients 2 and 3 each had a 64-fold, reduction in anti-alglucosidase alfa antibody titer, with concomitant sustained clinical improvement.

Conclusion: The addition of bortezomib to immunomodulatory regimens is an effective and safe treatment strategy in infantile Pompe disease, with potentially broader clinical implications.

Genet Med 2013:15(2):123-131

Key Words: antibodies; bortezomib; enzyme replacement therapy; glycogen storage disease type II; immune modulation

\section{BACKGROUND}

Protein replacement therapies have prolonged the survival and improved clinical outcomes of patients suffering from a multitude of disorders. However, therapeutic proteins are potentially immunogenic, eliciting antibody responses that reduce efficacy. ${ }^{1-5}$ Infantile Pompe disease (IPD) results from the deficiency of lysosomal acid a-glucosidase (GAA). Classic IPD is characterized by cardiomyopathy, hypotonia, respiratory insufficiency, and, if untreated, death before 2 years of age. ${ }^{6-8}$ Atypical, or nonclassic, patients with IPD present in infancy and typically do not have severe cardiomyopathy; and in some instances there is no cardiac involvement. Untreated patients with atypical IPD also have rapid disease progression, becoming wheelchair bound and/or ventilator dependent in the first few years of life. ${ }^{9}$ The availability of enzyme replacement therapy (ERT) with Chinese hamster ovary cell-line-derived recombinant human acid $\alpha$-glucosidase (rhGAA, alglucosidase alfa, Myozyme, Genzyme, Cambridge, MA) has led to significant improvements in overall survival and other clinical outcomes. ${ }^{10-12}$ However, complications from the immune response to ERT are an ongoing challenge in Pompe disease. Prior studies have demonstrated the negative impact of high sustained anti-rhGAA IgG antibody titers (high sustained antibody titers; HSATs) on clinical outcomes in IPD. ${ }^{2-4}$ More recently, there are reports of the negative impact of HSATs in adults with late-onset Pompe disease. ${ }^{13,14}$.

Some of the patients treated with alglucosidase alfa also develop IgE antibodies and appear to be at a higher risk for anaphylaxis and severe allergic reactions. ${ }^{15} \mathrm{IgE}$ is measured in the setting of a hypersensitivity reaction and is not routinely tested. The longer term therapeutic efficacy of alglucosidase alfa appears to be more strongly associated with anti-rhGAA IgG antibodies. The impact of IgE antibodies on clinical outcomes, in the absence of anaphylaxis, is still unclear and requires further investigation. In addition to the antibody response, ERT has also been shown to induce a T-cell response. ${ }^{16}$

IPD serves as an excellent model with which to evaluate immune tolerance induction (ITI) protocols as it is a rapidly progressive disease and any clinical interventions or factors altering 
efficacy of ERT tend to manifest rapidly via well-defined clinical end points. Recently, emerging clinical evidence regarding the effect of the immune response to ERT in IPD has spawned investigations into new approaches toward ITI designed both to preclude an immune response in the ERT-naive setting and to eliminate the immune response in patients with IPD who had only recently commenced ERT. ${ }^{17,18}$ Despite attempts at ITI in patients with IPD who developed HSAT, success has been elusive. ${ }^{19,20}$ Combinations of various drugs, such as rituximab, cyclophosphamide, and intravenous immunoglobulin (IVIG), and plasmapheresis in IPD with HSAT and in hemophilia have shown little success in reducing HSAT. ${ }^{19-23}$ Failure of these agents to reduce and sustain a reduced antibody titer can potentially be explained by the hitherto use of agents that do not target antibody-producing plasma cells. ${ }^{20,24}$ Bortezomib is a proteasome inhibitor that targets both short- and long-lived plasma cells, and is an agent of potential benefit in eliminating HSAT. ${ }^{25,26}$

Herein we present three patients with IPD treated with ERT who, despite initial clinical improvement, subsequently declined following the development of HSAT. All three patients were treated with a bortezomib-based immunomodulatory regimen.

\section{METHODS}

We included patients who met criteria for IPD (classic or atypical) with anti-rhGAA IgG antibody titers of $\geq 1: 51,200$ on two different occasions at/or beyond 6 months post-ERT initiation.
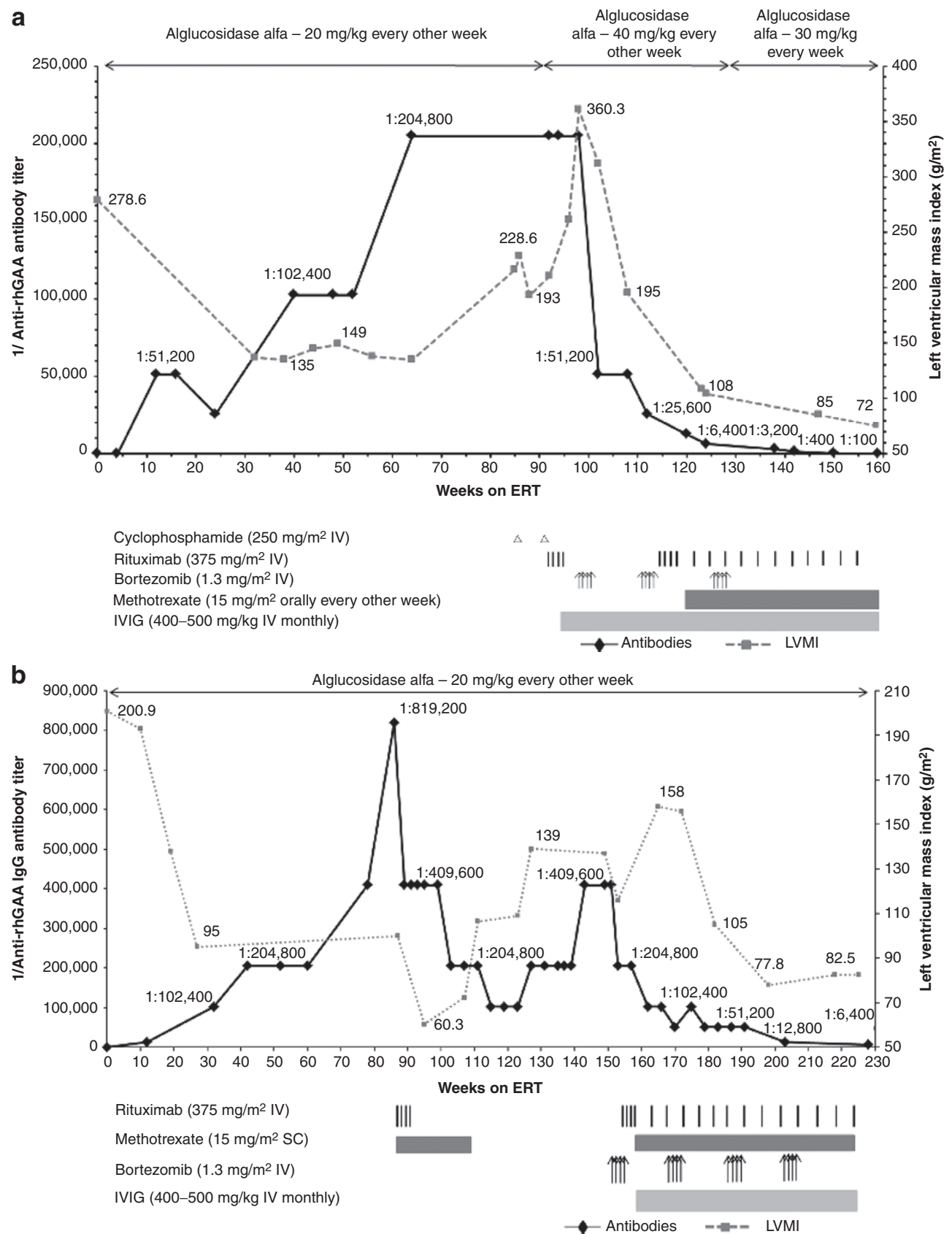
Patients 1 and 2 met the criteria for classic IPD: $\leq 1 \%$ of normal GAA activity (in skin fibroblasts and/or muscle biopsy), cardiomyopathy (left-ventricular mass index (LVMI) $\geq 65 \mathrm{~g} / \mathrm{m}^{2}$ by echocardiogram), and presentation within the first year of life. Patient 3 had atypical IPD without cardiomyopathy and presented in the first year of life. Cross-reactive immunologic material (CRIM) status was determined as described earlier based on the reactivity of a pool of monoclonal and polyclonal anti-GAA antibodies capable of recognizing both native and recombinant GAA. ${ }^{27,28}$ A patient was designated as CRIMpositive if any of the GAA protein forms (unprocessed precursor band at $110 \mathrm{kDa}$ or any of the processed forms) were detectable on western blot analysis; a patient was designated as CRIM negative if none of these protein forms was detectable on western blots (processed and unprocessed). ${ }^{3}$ Anti-rhGAA antibody titers were serially evaluated by Genzyme, as recommended in the Myozyme package insert. ${ }^{29}$ The fold reduction in antibody titer was calculated by dividing the initial titer value by the current antibody titer value. Urinary glucose tetrasaccharide $\left(\mathrm{Glc}_{4}\right)$, a biomarker for overall glycogen burden in skeletal muscle, was determined by high-pressure liquid chromatography with UV detector and tandem mass spectrometry (electrospray ionization mass spectrometry), as previously described. ${ }^{30}$. After discussion with the Northern California Regional Kaiser Genetic Diseases Treatment Advisory Board, and after obtaining written parental informed consent, a trial of a bortezomib-based regimen was commenced in patient 1 . The parents of patients 2 and 3 agreed to physician-directed use of bortezomib as a life-saving measure. Bortezomib was available in both hospitals' formulary for pediatric use in refractory leukemia. The bortezomib-based regimen is outlined in Figure 1a-c for patients 1, 2, and 3, respectively.

\section{Case description and findings}

Patient 1. This patient, a 4-year-old Caucasian male, was diagnosed with IPD at the age of 5 months. Patient demographics, CRIM status, and mutation data are shown in Table 1. Diseaseassociated signs and symptoms were first noted at age 3 months and included hypotonia as well as feeding and sucking difficulties. He had significant cardiomegaly at 5 months. Baseline (i.e., before initiation of ERT) clinical parameters, including cardiac, motor, respiratory, and feeding status, and laboratory
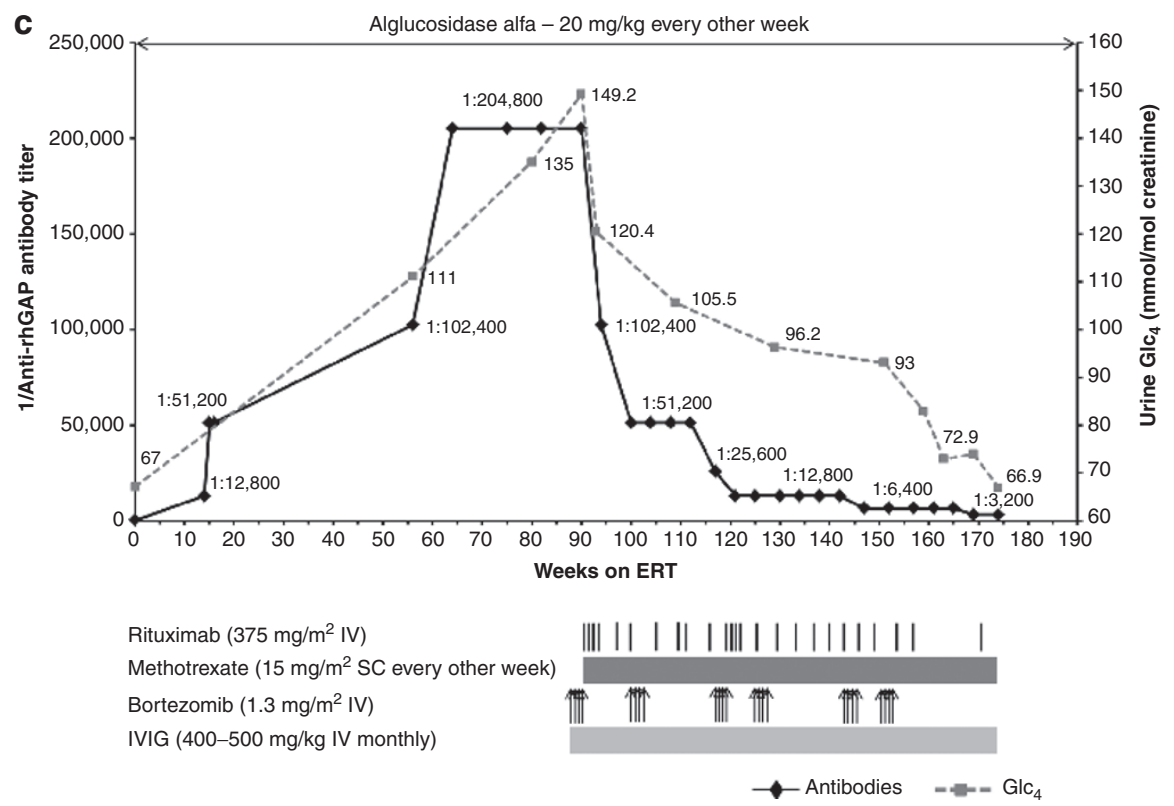

Figure 1 Trends in anti-recombinant human alglucosidase alfa (anti-rhGAA) IgG antibody titers and left-ventricular mass index (LVMI; (a and b) or urine $\mathrm{Glc}_{4}$ (c) over time are shown by a solid black line and a dashed gray line, respectively (the upper limit of normal $\mathrm{LVMI}$ is $65 \mathrm{~g} / \mathrm{m}^{2 ; 39}$ control range of urine $\mathrm{Glc}_{4}$ for age $>3$ years is $3 \mathrm{mmol} / \mathrm{mol}$ of creatinine). (a) In patient 1, following unsuccessful immunomodulation with two doses of cyclophosphamide $\left(250 \mathrm{mg} / \mathrm{m}^{2}\right.$ i.v. $)$ and four weekly doses of rituximab $\left(375 \mathrm{mg} / \mathrm{m}^{2}\right.$ per dose i.v.) during weeks 86 to 95 , monotherapy with bortezomib (Velcade) was initiated. Bortezomib was administered twice weekly $\left(1.3 \mathrm{mg} / \mathrm{m}^{2}\right.$ of body surface area i.v.) according to a standard dosing regimen (days 1 , 4 , 8, and 11; equivalent to one cycle of bortezomib)29 during weeks 99 and 100 (cycle 1), weeks 110 and 111 (cycle 2), and weeks 127 and 128 (cycle 3) of enzyme replacement therapy (ERT). Monthly intravenous immunoglobulin (IVIG) was administered at the start of the first cycle of bortezomib. Following a second cycle of bortezomib with continued ERT, a total of four weekly doses of i.v. rituximab $\left(375 \mathrm{mg} / \mathrm{m}^{2}\right.$ per dose) were administered in addition to biweekly methotrexate $\left(15 \mathrm{mg} / \mathrm{m}^{2}\right)$ orally. Rituximab was thereafter administered on a monthly basis. (b) In patient 2, following unsuccessful immunomodulation with rituximab $\left(375 \mathrm{mg} / \mathrm{m}^{2}\right.$, i.v. ) and methotrexate $\left(15 \mathrm{mg} / \mathrm{m}^{2}\right.$ s.c.) , bortezomib was administered as described in patient 1 . Following the first cycle of bortezomib, a total of four weekly doses of rituximab $\left(375 \mathrm{mg} / \mathrm{m}^{2}\right.$ per dose, i.v.) were administered in addition to biweekly methotrexate $\left(15 \mathrm{mg} / \mathrm{m}^{2}, \mathrm{~s} . \mathrm{c}.\right)$. Rituximab was thereafter administered on a monthly basis. Monthly IVIG was administered as described for patient 1. (c) In patient 3, bortezomib was administered as described for patient 1. Six such cycles were administered between weeks 88 and 153 . Rituximab was administered ( $375 \mathrm{mg} / \mathrm{m}^{2}$ per dose, i.v.) approximately every month except after the first and third cycle of bortezomib, at which time a total of four weekly doses were administered after the last bortezomib injection. Methotrexate and IVIG were administered as described in patients 1 and 2. 
Table 1 Patient demographics, cross-reactive immunologic material status, and mutation data

\begin{tabular}{|c|c|c|c|c|}
\hline \multicolumn{2}{|l|}{ 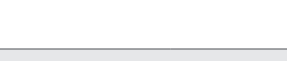 } & Patient 1 & Patient 2 & Patient 3 \\
\hline & Male & Male & Male \\
\hline \multicolumn{2}{|l|}{ Race } & Caucasian & Caucasian & Caucasian \\
\hline \multicolumn{2}{|l|}{ CRIM status } & Positive & Negative & Positive \\
\hline \multirow[t]{2}{*}{ Mutations } & Allele 1 & c. $307 \mathrm{~T}>\mathrm{G}$ & c. $2560 C>T$ & C. $1655 \mathrm{~T}>\mathrm{C}$ \\
\hline & Allele 2 & $\begin{array}{l}\text { c. } 2481+102 \\
\_2646+31 \mathrm{del}\end{array}$ & c. 1654delC & C. $1655 \mathrm{~T}>\mathrm{C}$ \\
\hline \multicolumn{2}{|c|}{ Age at symptom onset } & 3 months & 2 months & $<1$ month \\
\hline \multicolumn{2}{|c|}{ Age at diagnosis } & 5.0 months & 4.0 months & 3.5 years \\
\hline \multicolumn{2}{|c|}{ Age at ERT start } & 6.0 months & 4.5 months & 3.6 years \\
\hline
\end{tabular}

CRIM, cross-reactive immunologic material; ERT, enzyme replacement therapy.

parameters such as antibody titers and urinary Glc4 levels are shown in Tables 2-4. At age 6 months, the patient was started on ERT with alglucosidase alfa at $20 \mathrm{mg} / \mathrm{kg}$ every other week. Clinical improvement was noted shortly after the initiation of ERT, including improvements in cardiac and motor status (Tables 2-4).

Rising antibody titers. From a seronegative status at week 4 of ERT, anti-rhGAA antibody titers continued to rise, peaking at 1:204,800 at week 64 of ERT, and were maintained at 1:204,800 through week 86 . Concomitant with rising antibody titers was a progressive decline in clinical status and increase in urine $\mathrm{Glc}_{4}$ levels (Tables 2-4). The patient became fully ventilator dependent and required tube feeds. Anti-rhGAA IgG antibody titers and LVMI values over time are shown in Figure 1a.

Immunomodulation with cyclophosphamide and rituximab. Due to HSATs and concurrent clinical decline, ITI was initiated. Cyclophosphamide $\left(250 \mathrm{mg} / \mathrm{m}^{2}\right.$ i.v. $)$ monotherapy was administered at weeks 86 and 92 of ERT, followed by rituximab $\left(375 \mathrm{mg} / \mathrm{m}^{2}\right.$ i.v. $)$ every week from week 92 to week 95 post-ERT initiation (Figure 1), based on published reports. ${ }^{16,17}$ Despite elimination of a subset of B cells from peripheral blood, as evidenced by a CD19 count of $0 \%$, antibody titers remained persistently high at 1:204,800, and the patient continued to decline clinically in terms of cardiac, motor, and respiratory status (Tables 2-4). Increasing LVMI resulted in a near-complete left-ventricular cavity obstruction and significant left-ventricular outflow tract obstruction. At this time, he also had an increase in ventilation requirement. Urinary $\mathrm{Glc}_{4}$ levels peaked at $153.3 \mathrm{mmol} / \mathrm{mol}$ of creatinine. The patient was unable to move his arms or legs and his voluntary motor activity was limited to ocular movements.

Immunomodulation using bortezomib-based regimen and subsequent clinical improvement. Given the dire prognosis of this child, and the reasoning that rituximab-resistant, antibody-secreting plasma cells had to be eliminated, a trial of the bortezomib-based regimen was commenced (Figure 1a).
Following the first cycle of IV bortezomib monotherapy, antibody titers decreased from 1:204,800 to 1:51,200 (Figure 1a). Cycle two of bortezomib was combined with rituximab, methotrexate, and IVIG to preclude activation of rhGAA-specific naive and memory B- and T-cells and facilitate tolerance induction. This treatment resulted in a further decline of the antibody titer to 1:6,400 (Figure 1a). Following a third round of bortezomib in combination with rituximab and methotrexate, antibody titers were 1:100 at week 159 of ERT. The decline in antibody titers in this bortezomib-treated patient over time is in stark contrast to the persistence of HSATs in CRIM-negative and high-titer CRIM-positive patients, as well as in patients treated with a non-bortezomib-based immunomodulatory regimen (Supplementary Figure S1 online). ${ }^{19}$

The reduction in antibody titers following implementation of an immunomodulation strategy using bortezomib was in close temporal association with a period of marked and prolonged clinical improvement, including significant improvement in cardiac status, decreased ventilatory requirements, and improved motor status (Tables 2-4). The treatment regimen was well tolerated with no apparent side effects. At the time of this report, the patient is no longer receiving bortezomib. Rituximab dose intervals have been increased to 2 months. $\mathrm{He}$ continues on methotrexate and IVIG, the latter as clinically needed. The patient continues to receive alglucosidase alfa infusions at $30 \mathrm{mg} / \mathrm{kg}$ every week.

Patient 2. Patient 2 is a $4 \frac{1}{2}$-year-old male diagnosed with IPD at 4 months of age. Patient 2 demographics, CRIM status, and mutation data are shown in Table 1. This patient presented with a cardiac murmur at age 2 months and an echocardiogram showed significant biventricular hypertrophy. Physical exam at age 3 months showed signs of IPD (Tables 2-4). At age 4.5 months, he was started on alglucosidase alfa at $20 \mathrm{mg} / \mathrm{kg}$ every other week. Clinical improvement was observed after ERT initiation and included a reduction in LVMI and improved feeding (Tables 2-4).

Rising antibody titers. From a seronegative status at baseline antibody titers continued to rise and peaked at 1:819,200 at week 86 of ERT. Concomitant with rising antibody titers was a plateau of his gross developmental progress and increased urinary $\mathrm{Glc}_{4}$ (Tables 2-4).

Immunomodulation with rituximab and methotrexate. Given the rise in antibody titers, plateau in clinical response and his CRIM-negative status, an ITI protocol was initiated at week 87 that included rituximab $\left(375 \mathrm{mg} / \mathrm{m}^{2}\right.$ i.v., every week for 4 weeks and methotrexate $\left(15 \mathrm{mg} / \mathrm{m}^{2}\right.$ s.c. $)$ every other week. This regimen led to an eightfold decrease in antibody titers over 29 weeks: 1:819,200 at week 86 to 1:102,400 at week 115 . He maintained adequate physical activity and initially progressed in developmental motor milestones. Although there was an initial phase of improved LVMI, the values continued to deteriorate thereafter (Figure 1b, Tables 2-4). Even after his 
Table 2 Clinical and laboratory parameters over time for the three patients treated with bortezomib-based regimen (patient 1)

\begin{tabular}{|c|c|c|c|c|c|}
\hline & Baseline & $\begin{array}{l}\text { Initial improvement } \\
\text { phase }\end{array}$ & $\begin{array}{l}\text { Period of rising } \\
\text { anti-rhGAA IgG titers }\end{array}$ & $\begin{array}{l}\text { Immunomodulation } \\
\text { attempt with } \\
\text { cyclophosphamide } \\
\text { and rituximab }\end{array}$ & $\begin{array}{l}\text { Immunomodulation with } \\
\text { bortezomib-based regimen }\end{array}$ \\
\hline Anti-rhGAA IgG titers & Seronegative & $1: 25,600 \rightarrow 1: 102,400$ & $1: 102,400 \rightarrow 1: 204,800$ & $1: 204,800$ & $1: 204,800 \rightarrow 1: 100$ \\
\hline $\begin{array}{l}\text { Cardiac status } \\
\left(\text { LVMI }\left(\mathrm{g} / \mathrm{m}^{2}\right)\right)^{\mathrm{a}}\end{array}$ & 278.6 & 135 & $138.0 \rightarrow 228.6$ & $\begin{array}{l}228.6 \rightarrow 360.3 \text { (With } \\
\text { significant LVOTO; peak } \\
\text { velocity } 5.3 \mathrm{~m} / \mathrm{s} \text { ) }\end{array}$ & $\begin{array}{l}360.3 \rightarrow 72.0 \text { (With no } \\
\text { evidence of LVOTO) }\end{array}$ \\
\hline $\begin{array}{l}\text { Urinary Glc } \\
\text { (mmol/mol } \\
\text { creatinine) }\end{array}$ & $39.9^{b}$ & NA & 130.4c (Week 64) & 153.3` (Week 92) & 83.4 (Week 159) \\
\hline Gross motor status & $\begin{array}{l}\text { Generalized } \\
\text { hypotonia }\end{array}$ & $\begin{array}{l}\text { Sat unsupported; } \\
\text { rolled over; raised } \\
\text { arms against gravity; } \\
\text { bore weight on lower } \\
\text { extremities }\end{array}$ & $\begin{array}{l}\text { Regression of motor } \\
\text { milestones; myopathic } \\
\text { facies }\end{array}$ & $\begin{array}{l}\text { Voluntary motor } \\
\text { activity limited to ocular } \\
\text { movements only }\end{array}$ & $\begin{array}{l}\text { Reacquisition of previously } \\
\text { lost motor milestones; } \\
\text { regained ability to move } \\
\text { fingers and toes, bend knees } \\
\text { and nod head; recovery of } \\
\text { muscles of facial expression } \\
\text { and improvement in } \\
\text { speech function }\end{array}$ \\
\hline Respiratory status & $\begin{array}{l}\text { No respiratory } \\
\text { support }\end{array}$ & No respiratory support & $\begin{array}{l}\text { Full-time ventilator } \\
\text { dependent (PC/PEEP of } \\
18 / 6 \mathrm{~cm} \mathrm{H}_{2} \mathrm{O} \text {, breathing } \\
\text { rate: } 6 / \text { min) (week } 55 \\
\text { onward) }\end{array}$ & $\begin{array}{l}\text { Increase in ventilation } \\
\text { requirement (PC/PEEP of } \\
15 / 6 \mathrm{~cm} \mathrm{H}_{2} \mathrm{O} \text {, breathing } \\
\text { rate increased to } 30 / \mathrm{min})\end{array}$ & $\begin{array}{l}\text { Decrease in ventilation } \\
\text { requirement (PC/PEEP of } \\
15 / 5 \mathrm{~cm} \mathrm{H}_{2} \mathrm{O} \text {, breathing rate } \\
10 / \text { min); ability to come } \\
\text { off ventilator frequently for } \\
\text { short periods ( } 8-10 \mathrm{~min} \text { ) } \\
\text { (week } 159)\end{array}$ \\
\hline Feeding status & Oral & Oral & $\begin{array}{l}\text { Gastrostomy tube } \\
\text { (week } 55 \text { onward) }\end{array}$ & Gastrostomy tube & Gastrostomy tube \\
\hline
\end{tabular}

Baseline: before initiation of ERT.

ERT, enzyme replacement therapy; GAA, glucosidase $\alpha$; LVMI, left-ventricular mass index; LVOTO, left-ventricular outflow tract obstruction; NA, not available; PC/PEEP, pressure control/positive end-expiratory pressure; urinary $\mathrm{GlC}_{4}$, urinary glucose tetrasaccharide.

a Upper limit of normal LVMI: $65 \mathrm{~g} / \mathrm{m}^{2}$ (>2 SD higher than upper limit of the age-appropriate normal mean). ${ }^{\mathrm{b}} \mathrm{Control}$ value for ages 1 to $6 \mathrm{months:} 20 \mathrm{mmol} / \mathrm{mol}$ of creatinine (95th percentile). ' Control value for ages 1 to 3 years: $8 \mathrm{mmol} / \mathrm{mol}$ of creatinine. ${ }^{\mathrm{d}}$ Control range for ages $>3$ years: $3 \mathrm{mmol} / \mathrm{mol}$ of creatinine.

B-lymphocyte CD19 count dropped from $17.9 \%$ at the onset of rituximab and methotrexate therapy at week 87 to $0.1 \%$ at week 89 , antibody titers did not drop to $<1: 102,400$. The antibody titers continued to rise again and remained at peak levels of 1:409,600 from week 143 through week 153.

At age 3 years and 2 months (week 146 of ERT; 13 months after the last dose of rituximab and 9 months after the last dose of methotrexate), he developed an upper respiratory tract infection, which led to hospitalization and intubation. During his 6-week hospitalization, he was unable to be weaned from the ventilator; he required ventilator support at discharge (Tables 2-4). His cardiac, motor, and feeding status deteriorated while he was hospitalized, which was concurrent with increased urinary $\mathrm{Glc}_{4}$ levels (Tables 2-4).

Immunomodulation using bortezomib-based regimen and subsequent clinical improvement. A trial of bortezomib was commenced based on the following evidence: results of case 1 , worsening clinical status, lack of reduction of antibody titers below 1:102,400 with the rituximab and methotrexate regimen, and the known fact of poor outcome in patients with HSATs. Details of the bortezomib-based immunomodulatory strategy are described in Figure 1b. Following four cycles of bortezomib, in combination with rituximab, methotrexate, and IVIG, antibody titers decreased from 1:409,600 to 1:6,400. As in patient 1 , the decline in antibody titers in this bortezomibtreated patient over time is in stark contrast to the persistence of HSATs in CRIM-negative patients (Supplementary Figure S1 online). Likewise, the observed reduction in antibody titers, from 1:409,600 to 1:6,400, was closely associated in time with clinical improvement, including cardiac, motor, respiratory, and feeding status (Tables 2-4). He has had no hospitalizations or illnesses since the start of the bortezomibbased immunomodulatory regimen and has tolerated this regimen well, with no apparent side effects. The patient continues to receive alglucosidase alfa infusions at $20 \mathrm{mg} / \mathrm{kg}$ every other week.

Patient 3. Patient 3 is a 6-year and 10-month-old Caucasian male diagnosed with atypical IPD at age 3.5 years based on reduced GAA activity in muscle as well as extensive cellular vacuolization with glycogen accumulation. Patient 3 demographics, CRIM status, and mutation data are shown in Table 1. Symptoms began in the newborn period and included the findings shown in Tables 2-4. Echocardiogram and electrocardiogram findings remained within normal limits, confirming 
Table 3 Clinical and laboratory parameters over time for the three patients treated with bortezomib-based regimen (patient 2)

Patient 2

\begin{tabular}{|c|c|c|c|c|c|}
\hline & Baseline & $\begin{array}{l}\text { Initial improvement } \\
\text { phase }\end{array}$ & $\begin{array}{l}\text { Period of rising } \\
\text { anti-rhGAA IgG titers }\end{array}$ & $\begin{array}{l}\text { Immunomodulation } \\
\text { attempt with } \\
\text { cyclophosphamide } \\
\text { and rituximab }\end{array}$ & $\begin{array}{l}\text { Immunomodulation with } \\
\text { bortezomib-based regimen }\end{array}$ \\
\hline Anti-rhGAA IgG titers & Seronegative & $1: 12,800$ & $1: 102,400 \rightarrow 1: 819,200$ & $\begin{array}{l}1: 819,200 \rightarrow 1: 102,400 \\
\rightarrow 1: 204,800\end{array}$ & $1: 204,800 \rightarrow 1: 6,400$ \\
\hline $\begin{array}{l}\text { Urinary Glc } \\
\text { (mmol/mol creatinine) }\end{array}$ & NA & NA & $16.8^{b} \rightarrow 23.2^{b}$ & $23.2^{b} \rightarrow \mathrm{NA} \rightarrow 95.3^{\mathrm{b}}$ & $95.3^{b} \rightarrow 73.9^{c}$ \\
\hline Gross motor status & $\begin{array}{l}\text { Generalized } \\
\text { hypotonia; } \\
\text { head lag; facial } \\
\text { myopathy; } \\
\text { bilateral } \\
\text { ptosis; tongue } \\
\text { protrusion }\end{array}$ & $\begin{array}{l}\text { Clinical improvement } \\
\text { from baseline }\end{array}$ & $\begin{array}{l}\text { Plateau of gross } \\
\text { developmental progress }\end{array}$ & $\begin{array}{l}\text { Regression of gross } \\
\text { motor milestones; remained } \\
\text { wheelchair-bound; able to } \\
\text { sit with support; unable to } \\
\text { stand unassisted }\end{array}$ & $\begin{array}{l}\text { Stands with support; } \\
\text { increased extremity strength; } \\
\text { able to hold arms above body; } \\
\text { pushes against resistance }\end{array}$ \\
\hline Feeding status & Oral & Oral & Oral & $\begin{array}{l}\text { Nasogastric tube } \\
\text { (week } 146 \text { onward) }\end{array}$ & Oral \\
\hline
\end{tabular}

Baseline: before initiation of ERT.

ERT, enzyme replacement therapy; GAA, glucosidase $\alpha$; LVMI, left-ventricular mass index; NA, not available; PC/PEEP, pressure control/positive end-expiratory pressure; urinary $\mathrm{GlC}_{4}$, urinary glucose tetrasaccharide.

a Upper limit of normal LVMI: $65 \mathrm{~g} / \mathrm{m}^{2}$ (>2 SD higher than upper limit of the age-appropriate normal mean). ${ }^{\mathrm{b}} \mathrm{Control}$ value for ages 1 to 3 years: $8 \mathrm{mmol} / \mathrm{mol}$ of creatinine. ${ }^{c}$ Control range for ages $>3$ years: $3 \mathrm{mmol} / \mathrm{mol}$ of creatinine.

suspected atypical IPD. ERT with alglucosidase alfa was commenced at age 3.6 years at $20 \mathrm{mg} / \mathrm{kg}$ every other week. At this time, the patient required gastrostomy-tube feeds. Urine $\mathrm{Glc}_{4}$ level at baseline was $67 \mathrm{mmol} / \mathrm{mol}$ of creatinine (control value for age $>3$ years: $3 \mathrm{mmol} / \mathrm{mol}$ of creatinine). The patient showed a good clinical response to ERT within the first 6-8 months (26-34 weeks of ERT) as shown in Tables 2-4.

Rising antibody titers. From a seronegative status at baseline, antibody titers rose to $1: 204,800$ at week 64 of ERT, where they remained through week 90 (Figure 1c). Along with the rise in antibody titers, this patient started to decline clinically, including worsening of motor and respiratory status (Tables 2-4). This was simultaneous with increased urinary $\mathrm{Glc}_{4}$ levels (Figure 1c, Tables 2-4).

Immunomodulation using bortezomib-based regimen and subsequent clinical improvement. Given the rise in antibody titers and concurrent clinical decline, as well as our acquired experience with the two cases mentioned above, a bortezomibbased immunomodulatory regimen was initiated for patient 3 at week 88 of ERT. Details of the immunomodulatory strategy using bortezomib are described in Figure 1c. Following the first round of bortezomib (four doses) in combination with rituximab, methotrexate, and IVIG, the antibody titer dropped from 1:204,800 to 1:51,200 (Figure 1c). Subsequent administration of the bortezomib-based regimen resulted in further decline in antibody titers to 1:3,200 at week 169 of ERT (Figure 1c). Along with the drop in antibody titer, the patient experienced significant clinical improvement. There was a substantial reduction in ventilator requirements, as well as an overall increase in strength and energy, and significantly improved motor function (Tables 2-4). Improvements in speech and swallowing were also noted. Urine $\mathrm{Glc}_{4}$ levels continued to drop from a preimmunomodulatory value of 149.2 (week 88) to $66.9 \mathrm{mmol} /$ mol creatinine at week 169 (Figure 1c). The treatment regimen was well tolerated, with no evident side effects. The patient continues to receive alglucosidase alfa infusions at $20 \mathrm{mg} / \mathrm{kg}$ every other week.

\section{DISCUSSION}

At present, there are over 75 therapeutic proteins approved by the Food and Drug Administration for life-threatening and debilitating chronic diseases, with many more under development. A principal problem precluding the full clinical benefit derived from the use of these agents pertains to the elicitation 
Table 4 Clinical and laboratory parameters over time for the three patients treated with bortezomib-based regimen (patient 3)

Patient 3

\begin{tabular}{|c|c|c|c|c|}
\hline & Baseline & $\begin{array}{l}\text { Initial improvement } \\
\text { phase }\end{array}$ & $\begin{array}{l}\text { Period of rising } \\
\text { anti-rhGAA IgG titers }\end{array}$ & $\begin{array}{l}\text { Immunomodulation with } \\
\text { bortezomib-based regimen }\end{array}$ \\
\hline $\begin{array}{l}\text { Cardiac status } \\
\left(\text { LVMI }\left(\mathrm{g} / \mathrm{m}^{2}\right)\right)^{\mathrm{a}}\end{array}$ & WNL & WNL & WNL & WNL \\
\hline $\begin{array}{l}\text { Urinary Glc } \\
\text { (mmol/mol creatinine) }\end{array}$ & $67^{b}$ & NA & $111^{b} \rightarrow 149.2^{b}$ & $149.2 \rightarrow 66.9^{b}$ \\
\hline Respiratory status & $\begin{array}{l}\text { Required } \\
\text { continuous } \\
\text { ventilatory } \\
\text { support }\end{array}$ & $\begin{array}{l}\text { Improvement in ventilator } \\
\text { status (ability to spend } \\
1 \mathrm{~h} \text { daily off ventilator) }\end{array}$ & $\begin{array}{l}\text { Increased requirement for } \\
\text { ventilation; remained on } \\
\text { synchronized intermittent } \\
\text { mandatory ventilation without } \\
\text { a backup breath rate for } \\
1 \text { hour; increased need for } \\
\text { tracheostomy suction }\end{array}$ & $\begin{array}{l}\text { Decrease in ventilatory requirements } \\
\text { with ability to come off of the ventilator } \\
\text { for short periods of time; remains on } \\
\text { synchronized intermittent mandatory } \\
\text { ventilation without a backup breath } \\
\text { rate for the whole day; decreased } \\
\text { requirement for tracheostomy suction }\end{array}$ \\
\hline Feeding status & Gastrostomy tube & Gastrostomy tube & Gastrostomy tube & $\begin{array}{l}\text { Oral with improvement in swallow } \\
\text { function plus supplementary } \\
\text { gastrostomy tube feeds }\end{array}$ \\
\hline
\end{tabular}

Baseline: before initiation of ERT.

ERT, enzyme replacement therapy; GAA, glucosidase $\alpha$; LVMI, left-ventricular mass index; NA, not available; urinary Glc, urinary glucose tetrasaccharide; WNL, within normal limits.

aUpper limit of normal LVMI: $65 \mathrm{~g} / \mathrm{m}^{2}$ (>2 SD higher than upper limit of the age-appropriate normal mean). ${ }^{\mathrm{b}} \mathrm{Control}$ range for ages $>3$ years: $3 \mathrm{mmol} / \mathrm{mol}$ of $\mathrm{creatinine}$.

of immune responses, particularly when a therapeutic protein is immunologically perceived to be a foreign antigen. This represents a common challenge when considering treatment for patients with Pompe disease, mucopolysaccharidosis types I, II, and VI, Fabry disease, and hemophilias A and B., ${ }^{5,2431}$

There are various factors that could explain an immune response to a therapeutic protein, but in the patients with Pompe mounting such responses to rhGAA, the major factor is the genetic status of the patient, in which severe mutations in the GAA gene either fail to produce any enzyme or produce a defective enzyme that fails to tolerize the patients' immune systems. Thus, to such an untolerized immune system, the full-length human GAA appears as a foreign protein, to which an immune response is mounted. ${ }^{24}$ Other factors of importance in elicitation of immune responses to therapeutic proteins include the following: structural properties of a protein (e.g., sequence variation and glycosylation); impurities and contaminants; frequency and duration of treatment; genetic background of patients; route of administration; and other host and environmental factors. ${ }^{32}$

In patients who develop HSATs against ERT, not only can the prognosis be poor but sometimes it can be fatal. ${ }^{3,4,31}$ In addition to the human toll, the use of therapeutic proteins in patients who are not responding to the treatment because of interfering antibodies can have a large economic impact. Investigation of novel immunomodulatory strategies to preclude or reverse immune responses-and to induce immune tolerance in this setting-is not only critical in terms of therapeutic effect but also for optimal use of health-care resources.
These case studies demonstrate both the safety and efficacy of bortezomib as an immunomodulatory agent in the setting of a well-established immune response to a therapeutic protein. These are the first-known reported cases where successful induction of a prolonged decline in HSATs in a disease with therapeutic protein has been achieved by the use of a proteasome inhibitor (bortezomib). These cases demonstrate a direct relationship between the antibody response (titers and duration) and clinical response. In these three cases, treatment initiation with bortezomib was rapidly followed by sustained reductions in antibodies and clinical benefit. The rapid reduction in antibody titers occurred within a few weeks of starting the bortezomib-based regimen, with titers dropping from $1: 204,800$ to $1: 100 ; 1: 409,600$ to $1: 6,400$; and $1: 204,600$ to $1: 3,200$ in patients 1,2, and 3, respectively. This represents a 2,048-fold (patient 1) and 64-fold (patients 2 and 3) decline in titers as compared with titers at the time bortezomib was initiated. Of note, the marked and sustained decrease in antibody titers was associated with significant, durable improvement across all clinical outcome measures with continued improvement at the time of publication. Clearly, the benefits have been more robust in cardiac parameters as compared with the skeletal muscle response in patients 1 and 2. This is probably due to irreversible skeletal muscle damage that has been noted in other infantile survivors, despite long-term treatment with ERT. ${ }^{12,33}$

Urinary $\mathrm{Glc}_{4}$ levels correlate with overall glycogen burden and are useful for monitoring response to ERT,3,30. For all three patients, the increase in antibody titers correlated with an 
increase in urinary $\mathrm{Glc}_{4}$ levels and clinical decline. Conversely, the decrease in antibody titers associated with immunomodulation using the bortezomib-based regimen led to a reduction (albeit of variable magnitude) in urinary $\mathrm{Glc}_{4}$ levels and clinical improvement (Tables 2-4).

As with any immunosuppressive therapy, vaccination response might be diminished with the described bortezomib-based regimen. Live vaccines should be avoided while on treatment and immediately following treatment. Bortezomib is associated with peripheral neuropathy, neutropenia, thrombocytopenia, and gastrointestinal and cardiac side effects. However, no side effects were evident in any of these three patients treated with the bortezomib-based regimen. Total levels of different isotypes of immunoglobulin (total IgG, IgA, IgE, IgM, and IgD) stayed within normal ranges while on this regimen, except for two instances in patient 2 and one instance in patient 1 , wherein IgA levels were above normal limits (data not shown). Given the dramatic suppression of immunity, the patients were supplemented with monthly IVIG for infection prophylaxis and to potentially contribute to immunomodulation. ${ }^{34}$

Although the mechanism of action of bortezomib in reducing anti-rhGAA IgG antibodies is not precisely known in these cases, we speculate that it is due to proteasome inhibition in both short-lived and long-lived plasma cells. Bortezomib binds to the catalytic site of the $26 \mathrm{~S}$ proteasome with high affinity and specificity. There are various explanations for the actions of bortezomib and other proteasome inhibitors on plasma cells: (i) plasma cells are exceptionally sensitive to proteasome inhibitors due to their excessive protein (immunoglobulin) synthesis. Blocking the proteasome rapidly induces excessive endoplasmic reticulum stress and activation of the terminal unfolded protein response with induction of the proapoptotic protein and activation of caspases, leading to apoptosis; ${ }^{26}$ (ii) proteasome inhibition interferes with degradation of IкB (nuclear factor of $\kappa$ light polypeptide gene enhancer in B-cell inhibitors) proteins, thereby blocking activation of the transcription factor NF- $\kappa \mathrm{B}$ (nuclear factor $\kappa$-light-chain-enhancer of activated B-cells), which could contribute to bortezomib-induced plasma cell death; ${ }^{26}$ and (iii) bortezomib alters the microenvironment (e.g., interleukin-5 and interleukin-6, tumor necrosis factor- $\alpha$ ) required for plasma cell survival and could play a role in its elimination. ${ }^{26}$ In addition to its primary action on plasma cells, bortezomib has also been found to act on both $\mathrm{T}$ and $\mathrm{B}$ cells, thereby further modulating the humoral antibody response. ${ }^{35}$

As a proteasome inhibitor, bortezomib may also directly act on muscle in the context of IPD. The ubiquitin-proteasome system is believed to degrade the major contractile skeletal muscle proteins and to play a critical role in muscle wasting. Muscle wasting is a prominent feature of IPD and is similar to other muscle wasting disease states, such as cancer cachexia, sepsis, diabetes, and metabolic acidosis, in which expression of the ubiquitin-proteasome proteolytic pathway is increased in skeletal muscle. ${ }^{8,36}$ Thus, blockade of the proteasome in muscle has the potential to mitigate skeletal muscle wasting and damage, which has been demonstrated preclinically in Duchenne and Becker muscular dystrophies as well as in rat models of denervation-induced muscular atrophy. ${ }^{37,38}$

Recent reports have demonstrated the successful use of immunomodulatory regimens based on rituximab, methotrexate, and either with or without IVIG, in the ERT-naive or early-ERT settings. ${ }^{17,18}$ At present, we do not have enough evidence for the use of the bortezomib-based immunomodulatory regimen described here in the ERT-naive or early-ERT settings. Conservatively, it appears that this bortezomib-based immunomodulatory regimen should be used in patients with (i) antibody titers of $\geq 51,200$ on two or more occasions at or beyond 6 months of ERT, as they seem to be at highest risk of clinical decline following the development of $\mathrm{HSATs}^{4}$ and/or (ii) an increasing trend or persistence of antibody titers (regardless of titer value) with associated clinical decline.

As used in these three patients, a combination of drugs that target B cells, T cells, and plasma cells is needed to achieve long-term remission of antibodies and potential induction of immune tolerance, as depicted in Supplementary Figure S2 online. In these cases, the combination of rituximab, methotrexate, and IVIG in addition to bortezomib appeared to be both safe and efficacious, with each drug acting on a different part of the pathway leading to antibody production (Supplementary Figure S2 online).

The immunomodulatory approach described herein represents a promising new strategy for patients with entrenched immune responses to protein replacement therapies. It may also prove successful in addressing autoimmune disorders that fail to respond to agents targeting only $\mathrm{T}$ and $\mathrm{B}$ cells, such as rituximab and methotrexate. Thus, this immunomodulatory approach should be considered for further study in a variety of settings where patient immune response is implicated in the disease pathogenesis itself or in reduced effectiveness of the respective protein therapy.

\section{SUPPLEMENTARY MATERIAL}

Supplementary material is linked to the online version of the paper at http://www.nature.com/gim

\section{ACKNOWLEDGMENTS}

The authors thank the patients who participated in this clinical study and their families. They also thank the study coordinators, nurses, and technical staff at the various treatment centers. The opinions and information in this article are those of the authors, and do not necessarily represent the views and/or policies of the US Food and Drug Administration.

\section{DISCLOSURE}

P.S.K. reports receiving research and grant support from Genzyme. P.S.K. also receives honoraria and consulting fees from Genzyme and is a member of the Pompe disease and the Gaucher Disease Registry Advisory Boards. Duke University and the inventors of the method of treatment and precursors of the cell lines used to generate the enzyme (rhGAA) used commercially have received royalties pursuant to the University's policy on inventions, patents, and 
technology transfer. This potential conflict for Duke University has been resolved through monetization. S.G.B., S.N.P., and P.S.K. are listed as inventors on a Duke University pending patent application for the work described in this article. To date, neither Duke University nor the inventors have received any money from rights associated with this pending patent. D.V. receives clinical research support from Genzyme and serves as a board member for the MPS I Registry in which honoraria are provided for attendees at meetings by the host company, Genzyme. The other authors declare no conflict of interest.

\section{REFERENCES}

1. Porter S. Human immune response to recombinant human proteins. J Pharm Sci 2001;90:1-11.

2. Amalfitano A, Bengur AR, Morse RP, et al. Recombinant human acid alphaglucosidase enzyme therapy for infantile glycogen storage disease type II: results of a phase l/ll clinical trial. Genet Med 2001;3:132-138.

3. Kishnani PS, Goldenberg PC, DeArmey SL, et al. Cross-reactive immunologic material status affects treatment outcomes in Pompe disease infants. Mol Genet Metab 2010;99:26-33.

4. Banugaria SG, Prater SN, Ng YK, et al. The impact of antibodies on clinical outcomes in diseases treated with therapeutic protein: lessons learned from infantile Pompe disease. Genet Med 2011;13:729-736.

5. Hollak CE, Linthorst GE. Immune response to enzyme replacement therapy in Fabry disease: impact on clinical outcome? Mol Genet Metab 2009;96:1-3.

6. Kishnani PS, Hwu WL, Mandel H, Nicolino M, Yong F, Corzo D. A retrospective, multinational, multicenter study on the natural history of infantile-onset Pompe disease. J Pediatr 2006;148:671-676.

7. van den Hout HM, Hop W, van Diggelen OP, et al. The natural course of infantile Pompe's disease: 20 original cases compared with 133 cases from the literature. Pediatrics 2003;112:332-340.

8. Hirschhorn R, Reuser AJJ. Glycogen storage disease type II: acid a-glucosidase (acid maltase) deficiency. In: Valle D, Scriver CR, eds. Scriver's Ommbid The Online Metabolic \& Molecular Bases of Inherited Disease. McGraw-Hill: New York, 2009. http://genetics.accessmedicine.com/.

9. Kishnani PS, Steiner RD, Bali D, et al. Pompe disease diagnosis and management guideline. Genet Med 2006;8:267-288.

10. Kishnani PS, Corzo D, Nicolino M, et al. Recombinant human acid (alpha)glucosidase: major clinical benefits in infantile-onset Pompe disease. Neurology 2007;68:99-109.

11. Nicolino M, Byrne B, Wraith JE, et al. Clinical outcomes after long-term treatment with alglucosidase alfa in infants and children with advanced Pompe disease. Genet Med 2009;11:210-219.

12. Kishnani PS, Corzo D, Leslie ND, et al. Early treatment with alglucosidase alpha prolongs long-term survival of infants with Pompe disease. Pediatr Res 2009;66:329-335.

13. de Vries JM, van der Beek NA, Kroos MA, et al. High antibody titer in an adult with Pompe disease affects treatment with alglucosidase alfa. Mol Genet Metab 2010;101:338-345.

14. Patel TT, Banugaria SG, Case LE, Wenninger S, Schoser B, Kishnani PS. The impact of antibodies in late-onset Pompe disease: A case series and literature review. Mol Genet Metab 2012;106:301-309.

15. Myozyme. [Package Insert]. Genzyme Corporation: Cambridge, MA, 2006.

16. Banati M, Hosszu Z, Trauninger A, Szereday L, Illes Z. Enzyme replacement therapy induces T-cell responses in late-onset Pompe disease. Muscle Nerve 2011:44:720-726.

17. Messinger $Y H$, Mendelsohn NJ, Rhead W, et al. Successful immune tolerance induction to enzyme replacement therapy in CRIM-negative infantile Pompe disease. Genet Med 2012;14:135-142.
18. Mendelsohn NJ, Messinger YH, Rosenberg AS, Kishnani PS. Elimination of antibodies to recombinant enzyme in Pompe's disease. N Engl J Med 2009;360:194-195.

19. Hunley TE, Corzo D, Dudek M, et al. Nephrotic syndrome complicating alpha-glucosidase replacement therapy for Pompe disease. Pediatrics 2004;114:e532-e535.

20. Banugaria SG, Patel TT, Mackey J, et al. Persistence of high sustained antibodies to enzyme replacement therapy despite extensive immunomodulatory therapy in an infant with Pompe disease: need for agents to target antibody-secreting plasma cells. Mol Genet Metab 2012;105:677-680.

21. Biss TT, Velangi MR, Hanley JP. Failure of rituximab to induce immune tolerance in a boy with severe haemophilia A and an alloimmune factor VIII antibody: a case report and review of the literature. Haemophilia 2006;12: 280-284.

22. Hruby MA, Schulman I. Failure of combined factor VIII and cyclophosphamide to suppress antibody to factor VIII in hemophilia. Blood 1973;42:919-923.

23. Collins PW, Mathias M, Hanley J, et al. Rituximab and immune tolerance in severe hemophilia A: a consecutive national cohort. J Thromb Haemost 2009;7: 787-794.

24. Wang J, Lozier J, Johnson G, et al. Neutralizing antibodies to therapeutic enzymes: considerations for testing, prevention and treatment. Nat Biotechnol 2008;26:901-908.

25. Richardson PG, Barlogie B, Berenson J, et al. A phase 2 study of bortezomib in relapsed, refractory myeloma. N Engl J Med 2003;348:2609-2617.

26. Neubert K, Meister S, Moser K, et al. The proteasome inhibitor bortezomib depletes plasma cells and protects mice with lupus-like disease from nephritis. Nat Med 2008;14:748-755.

27. Kishnani PS, Nicolino M, Voit T, et al. Chinese hamster ovary cell-derived recombinant human acid alpha-glucosidase in infantile-onset Pompe disease. J Pediatr 2006;149:89-97.

28. Klinge L, Straub V, Neudorf $U$, et al. Safety and efficacy of recombinant acid alpha-glucosidase (rhGAA) in patients with classical infantile Pompe disease: results of a phase II clinical trial. Neuromuscul Disord 2005;15: 24-31.

29. Velcade. [Package Insert]. Millenium Pharmaceuticals: Cambridge, MA, 2010.

30. Young SP, Piraud M, Goldstein JL, et al. Assessing disease severity in Pompe disease: the roles of a urinary glucose tetrasaccharide biomarker and imaging techniques. Am J Med Genet C Semin Med Genet 2012;160:50-58.

31. Ragni MV, Ojeifo O, Feng J, et al. Risk factors for inhibitor formation in haemophilia: a prevalent case-control study. Haemophilia 2009;15:10741082.

32. Schellekens $\mathrm{H}$. Factors influencing the immunogenicity of therapeutic proteins. Nephrol Dial Transplant. 2005;20(suppl 6):vi3-9.

33. Prater SN, Banugaria SG, Dearmey SM, et al. The emerging phenotype of long-term survivors with infantile Pompe disease. Genet Med 2012;14: 800-810.

34. Hall PD. Immunomodulation with intravenous immunoglobulin. Pharmacotherapy 1993;13:564-573.

35. Lemy A, Toungouz M, Abramowicz D. Bortezomib: a new player in pre- and post-transplant desensitization? Nephrol Dial Transplant 2010;25: 3480-3489.

36. Tisdale MJ. Is there a common mechanism linking muscle wasting in various disease types? Curr Opin Support Palliat Care 2007;1:287-292.

37. Gazzerro E, Assereto S, Bonetto A, et al. Therapeutic potential of proteasome inhibition in Duchenne and Becker muscular dystrophies. Am J Pathol 2010;176:1863-1877.

38. Beehler BC, Sleph PG, Benmassaoud L, Grover GJ. Reduction of skeletal muscle atrophy by a proteasome inhibitor in a rat model of denervation. Exp Biol Med (Maywood) 2006;231:335-341.

39. Vogel M, Staller W, Bühlmeyer K. Left ventricular myocardial mass determined by cross-sectional echocardiography in normal newborns, infants, and children. Pediatr Cardiol 1991;12:143-149. 